\title{
Teknologi Tepat Guna PELATIHAN KETRAMPILAN MEMBUAT POT UNTUK ANAK
}

\author{
Iqbal Maimun Umar ${ }^{1}$, Joni Nur Budi ${ }^{2}$, \\ ${ }^{1}$ Universitas Multimedia Nusantara \\ ${ }^{2}$ Universitas Multimedia Nusantara \\ iqbal.oemar@lecturer.umn.ac.id,joni@umn.ac.id
}

\begin{abstract}
Abstrak
Di era pandemi ini aktifitas dikerjakan di rumah (WFH) Work From Home. Demikian pula anak-anak mengikuti kelas secara online. Selain itu ada kegiatan lain seperti bermain game online. Dalam keseharian kegiatan anak-anak juga membutuhkan gerak di luar rumah (outdor), karena tubuh kita perlu gerak dan cahaya supaya tubuh tetap imun, seperti mengikuti pelatihan ketrampilan pembuatan pot. Metode yang digunakan tahap persiapan adalah observasi mengamati kondisi penghijauan sekitar lingkungan yang dijadikan lokasi PKM. Teknis pelaksanaan mengajarkan langsung dari dasar (basic) dengan cara memberi contoh cara pembutan, kemudian anak-anak mempraktekan bersama dengan karya masing-masing. Dampak lain diharapkan dapat menumbuhkan kreatifitas motorik anak lebih aktif sehingga dapat menghasilkan karya yang artistik. Manfaat ke depan anak dapat mengembangkan lebih lanjut dan menumbuhkan percaya diri kelak dapat jadi bekal kewirausahaan.
\end{abstract}

Kata Kunci : PKM, Ketrampilan, membuat pot

\section{PENDAHULUAN}

Dalam kondisi pandemi sekarang ini, sebagian kegiatan dilakukan di rumah dan sekitarnya, aktifitas kantor, sekolah fasilitas umum dihentikan sementara. Anak-anak pun selama setahun di rumah. Selain mengikuti sekolah online juga mengikuti kegiatan di sekitar rumah misal membantu orang tua atau mendalami kegiatan tambahan misalnya membuat ketrampilan. Jenis ketrampilan dapat beragam seperti membuat pot.
Akhir tahun 2019 ada kecenderungan masyarakat menyenangi bersepeda. Dicky Budiman epidemiolog dari Grifith University mengatakan bahwa tren bersepeda memang menjadi booming di dunia saat pandemi.

Di awal Januari 2020 booming tanaman yang cukup terkenal adalah tanaman Janda Bolong, Keladi, Philo Dendrone. Tingginya permintaan tanaman hias memicu kebutuhan pot kembang. Jenis pot kembang yang popular adalah pot plastik karena lebih ringan dan murah. Namun ada 
masyarakat yang menyukai pot dengan bahan yang lain berbahan semen, gerabah, keramik, rotan, kayu.

Ukuran pot bisa beragam tergantung pohon yang ditanam. Dari sisi bentuk sangat variatif di bagian lubang mulut (tepian) pot ada yang bulat, segi empat, segi lima $(3,6)$, ada yang oval. Ketigian disesuaikan dengan diameter pot, khusus pot bonsai lebih lebar mulut potnya dibanding ketinggiannya.

Karena pentingnya pot dalam kehidupan sehari hari maka kami memilih topik ini sebagai PKM. Lokasi PKM dipilih disekitar kediaman supaya dapat mengurangi aktifitas di lingkungan luar wilayah. Lokasinya di Kampung Jatirangon, Rt. 03 Rw. 08 Jatirangon Jatisampurna Bekasi. Di daerah ini kesadaran bercocok tanam sangat tinggi namun keterbatasan lahan menjadi kendala untuk menanam tanaman hias, solusinya dengan menggunakan pot tidak jadi hambatan menyalurkan kecintaan terhadap bercocok tanam. Sehingga kampung lebih asri dan dapat mengurangi kesan kumuh.

Pemilihan target PKM adalah anak-anak 10-15 karena umur ini kreatifitasnya baru berkembang, kegiatan yang positif dapat mengurangi kegiatan yang monoton misal main game sepanjang waktu. Dari usia ini pula memorinya sangat baik sehingga kelak dapat mengingat dan mempraktekan guna alternatif bidang usaha.

Kegiatan pembuatan pot ini seperti permainan anak-anak karena ada proses mencetak dengan pasir kemudian dilapisi adukan semen. Selain memerlukan kreatifitas yang tinggi dapat memicu keiingintahuan (penasaran, surprise) anakanak. Serta menumbuhkan tantangan dalam membangun bentuk tiga dimensi dari dasar hingga puncaknya. Hal ini diperlukan latihan terus-menerus dan kesabaran yang tinggi.

Kegiatan pelatihan pembuatan pot ini penting ini di masa pandemi ini, merupakan salah satu kegiatan bermanfaat. Selain itu dapat melatih kecerdasan gerak lebih terampil, spontan. Dan menumbuhkan daya cipta yang tinggi serta untuk jiwa wirausaha.

\section{METODE}

Kegiatan pelaksanaan Pengabdian kepada Masyarakat sesuai dengan metode pelaksanaan yang dipilih, contohnya di dalam metode pengabdian dilakukan beberapa tahapan kerja, yaitu

1. Persiapan

Memetakan permasalahan baik lokasi dan situasi khususnya penghijauan. Serta pengamatan aktifitas anak setiap harinya. Hal ini terkait target pelatihan ketrampilan yg ditujukan ke anak-anak. Menyiapkan bahan yang akan digunakan. Mengurus perizinan. Merencanakan kerangka kerjanya.

2. Pelaksanaan, Mengundang 10 peserta namun yang berhasil mengikuti 5 peserta, 2 Instruktur dan 2 dosen aparat setempat RT, RW menyiapkan lokasi workshop, peralatan, souvenir, konsumsi dll

3. Pengujian dan Evaluasi Hasil, Setelah terlaksana hasil dapat dimonitoring dan evaluasi kwalitasnya. Kalau diperlukan akan ada pendalaman latihan lagi karena tidak cukup satu sampai tiga pertemuan untuk melancarkan tahap demi tahap.

\section{HASIL DAN PEMBAHASAN}

\section{Pelaksanaan}

Pada tanggal Kamis 24 Juni 2021 PKM Pelatihan Ketrampilan Pembuatan Pot telah dilaksanakan dari pukul 3.30 hingga 17.30. kegiatannya meliputi Pembukaan PKM arahan umum dan doa bersama, saya didampingi oleh aparat ketua RT juga merangkap sebagai instruktur. Peserta yang mengikuti pelatihan terdiri dari 5 anak. Personil pendukung dari event ini terdiri dari 7 orang yang masing-masing mempunyai tugas dan tanggung jawabnya. Seperti Vidiografi yang mengabadikan seluruh momen kegiatan PKM dari 
awal hingga akhir. Yang lainnya Tim Konsumsi 2 orang yang menyiapkan kudapan berupa bakso yang disajikan di jeda waktu kegiatan. Serta tim editing dan layout buku. Semua ikut mengamati proses berlangsungnya kegiatan agar paham apa yang akan disampaikan ke dalam vidio dan buku tutorial.

Gambar 1. Dokumen Pribadi Proses Mencetak

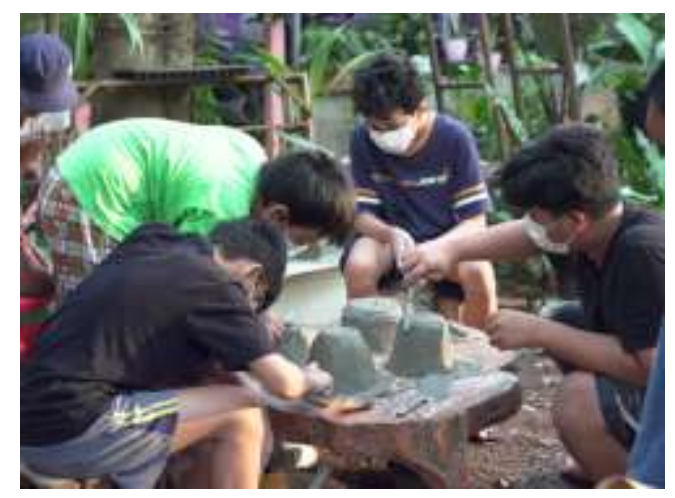

Gambar 2. Dokumen Pribadi Proses Mencetak

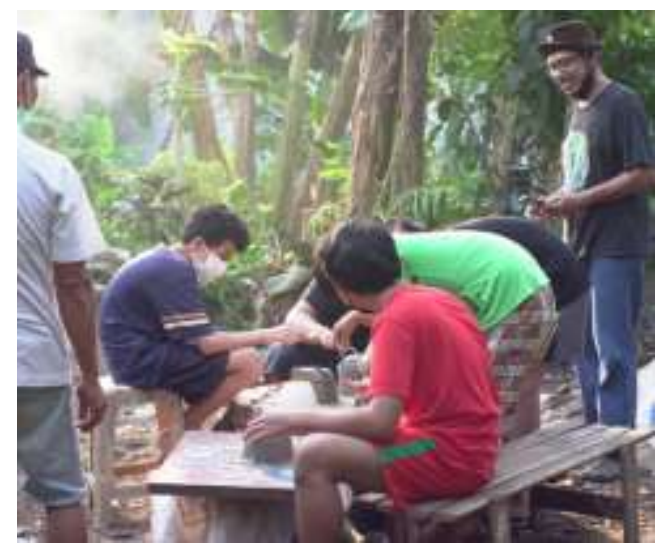

Dalam kegiatan pelatihan ketrampilan membuat pot ini sangat singkat waktunya, walau sudah direncanakan selesai dalam tempo 2-3 jam masih belum tuntas. Sehingga ada perpanjangan waktu kegiatan yang tidak terencana hingga Jumat pagi dan sore tahapan penghalusan (bongkar cetakan, acian, painting), dilanjutkan pada hari Sabtu sore penanaman, pada akhirnya kami mengijinkan dibawa pulang untuk menunjukan ke orang tuanya hasil karya PKM.
Respon positif dari orang tua ketika kegiatan PKM ini ada di WA grup. Atau di media sosial Facebook. Ada seorang ibu yang berterimakasih bahwa anaknya diberi kesempatan mengikuti PKM ini. Ada pula yang datang langsung ke rumah memberi tanggapan bahwa aktifitas ini dapat mengurangi anak kebiasaan menggunakan dadget. Karena orang tua jenuh melihat anak yang sepanjang hari hanya bermain game di hpnya.

Kegiatan PKM luar ruang dapat mengasah motorik, bergerak leluasa melatih jemari, emosi, dan rasional seperti dari ketebalan pot perlu di pertimbangkan supaya kuat. Menurut Kartini Kartono (1995: 83) motorik halus adalah ketangkasan, keterampilan, jari tangan dan pergelangan tangan. Semakin banyak dilatih tangan semakin trampil, tangkas, gerakan tangan dapat memproduksi ketepatan dimensi pot.

Dalam hal ini setiap lingkaran pot yang dapat dirasakan kesempurnaan oval/kurva yang dapat melatih rasa. Jam 15.30 mentari masih sangat panas yang dapat memicu semangat berkarya hingga keringat membasahi kaosnya. Hal ini dapat menambah imun tubuh di saat pandemi ini.

\section{Bahan dan peralatan}

Bahan diperlukan dalam pembuatan Pot adalah Semen Pasir putih bangka dan Air, cat acrylic, cat minyak, Thiner, sedang peralatannya sendok semen, sendok nasi, sendok palet, busa, sarung tangan, baskom, mangkok, ember, cetakan pot plastik, kuwas.

\section{Proses Pembuatan POT}

Tahapan dalam pembuatan Pot, membuat cetakan dari pot plastik yang dapat diperoleh di toko pot, dengan berbagai ukuran dan jenis. 


\section{Diagram : Proses Pembuatan Pot}

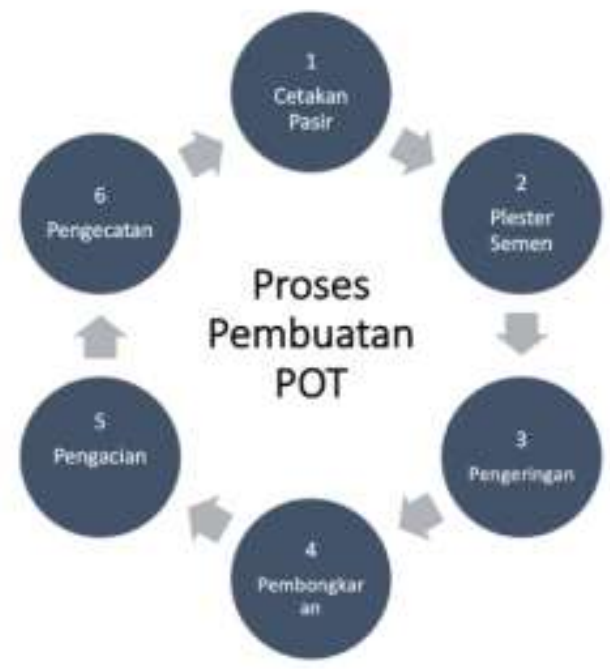

Dalam kesempatan ini kita menyediakan cetakan dengan ukuran kecil diameter $15 \mathrm{~cm}$ yang sudah dilobangi di bagian bawah, berikut step cara pembuatan :

1. Mengisi pasir ke dalam cetakan plastik dan dipadatkan. Tahap ini sangat mudah dan fun dilakukan karena si anak seperti bermain pasir sambil membentuk berdasarkan molding (cetakan plastik).

2. Meplester cetakan pasir dengan adukan semen. Tahap ini perlu ketangkasan karena menempelkan semen ke cetakan pasir. Tidak hanya memplester tapi juga merasakan ketebalan. Dalam teknik ini kita tidak dapat menentukan ketebalan karena di plester dengan cara manual. Tidak menggunakan alat sebagai patokan.

3. Setelah diplester perlu menunggu pengeringan semen selama 24 jam. Dalam workshop hari pertama sudah diperagakan hasil pengeringan. Namun anak-anak tetap menunggu pengeringan karyanya sampai keesokan hari.

4. Di hari berikutnya (hari 2) membongkar cetakan pasir, dengan sendok nasi pasir dikerok lalu dibersihkan dengan semprotan air.
5. Setelah dibersihan tahap dihaluskan dengan pengacian supaya terlihat rapi.

6. Tahap finalisasi pewarnaan dengan cat dasar dan melukis menghias supaya lebih menarik. Ditahap ini anak dibebaskan untuk berkreasi sesuai dengan kreatifitas melukis masing-masing. Berbekal latihan melukis dalam kegiatan beberapa tahun yang lalu. Sehingga ditahap ini tidak membutuhkan pendalaman yang lama. Fokus PKM ini mencetak pot jadi untuk pewarnaan sebagai pelengkap dalam kegiatan.

Gambar 3. Dokumen Pribadi Proses Mewarnai

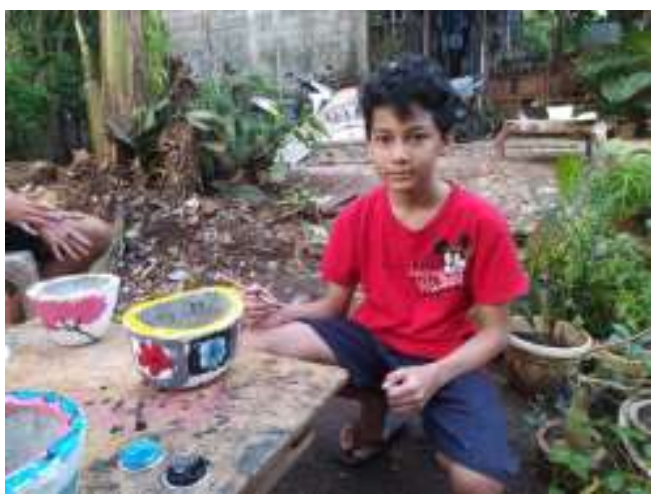

Gambar 4. Dokumen Pribadi Proses Mewarnai

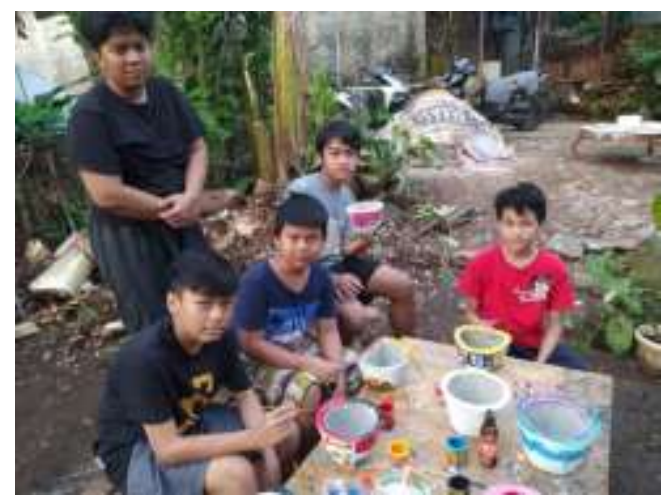

Gambar 5. Dokumen Pribadi Proses Mewarnai 


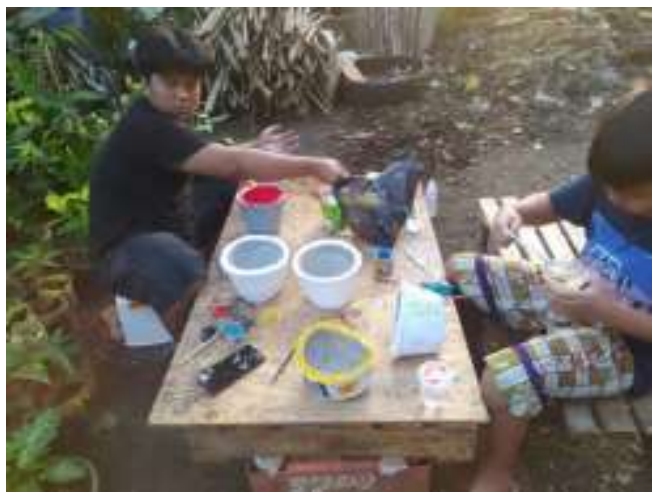

Gambar 6. Dokumen Pribadi Proses Mewarnai

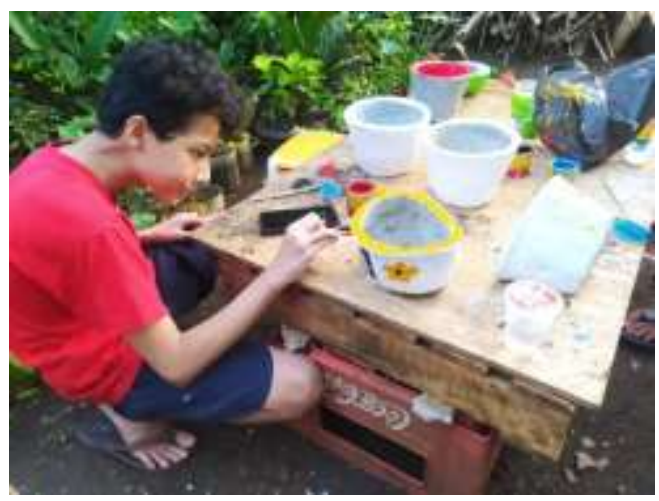

\section{Perancangan Buku Tutorial}

Target buku anak remaja usia produktif, pencipta lapangan pekerjaan. Kreatifitas berkembang diusia tersebut tentunya untuk bisnis menghasilkan karya yang dapat dipasarkan.

\section{Content buku :}

Judul Buku : 5 cara membuat pot

1. Teknis cetak pasir

2. Teknis cetak pasir 2

3. Teknis cetak mal

4. Cetak media baskom

5. Cetak pot bonsai
Kelima sistem cetak pot tersebut sebagian sudah diterapkan selebihnya diambil dari data yang telah dihimpun dari internet. Namun buku ini sebagian merupakan hasil dari PKM dari Universitas Multimedia Nusantara, pesertanya adalah anak-anak dari SD hingga SMP. Yang dilaksanakan pada saat Pandemi tujuannya selain untuk menumbuhkan kreatifitas untuk mengisi waktu diluar kegiatan keseharian antara lain belajar online. Kegiatan ini untuk selingan diantara kegiatan online supaya tidak monoton. Pembuatan pot ini dilakukan di outdor, dibutuhkan gerak tubuh dan olah rasa, sensitifitas dan kreatifitas. Tahap pencetakan pasir dibentuk sendiri ini butuh ketelitian pembentukan demensi yang sempurna, menumbuhkan keingintahuan dan semangat berkreasi saja. Mengenai hasil dapat dilatih terus menerus hingga menghasilkan karya pot yang baik dapat digunakan atau diperjualbelikan.

Selain penampilan pot yang menarik tentunya kekuatan pot juga yang prioritas, ketika diisi media tanam tidak retak atau pecah, tentu melalui proses dan tahapan yang benar, dalam tutorial buku ini akan dijabarkan secara mendalam, dan akan dicetak dalam bentuk buku (fisik) serta dapat di-download dalam bentuk pdf.

\section{Hasil Vidio}

Sebelum membuat video ini kami sudah mencari referensi video tutorial serupa dan berbagai teknis ada yang menggunakan cetakan pasir ada pula yang menggunakan media lain, jenis bentuknya juga cukup beragam. Berikut referensi Vidio sejenis membuat kerajinan Pot bunga berbahan tanah liat untuk anak SD dari youtube. 


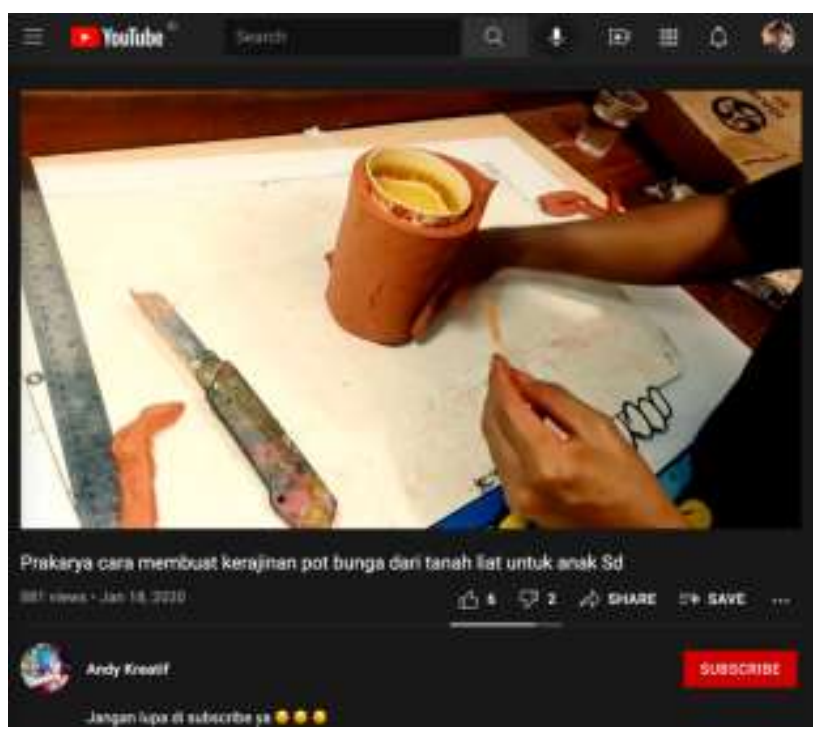

Gambar 7 Referensi

https://www.youtube.com/watch?v=A3eTZAef1Wc

Dari referensi diatas hanya menunjukan bahan tanah liat (terakota) untuk pembuatan pot. Visualisasi dalam gambar perlu yang jelas bersih, peralatan yang baru sehingga hasil video terlihat rapi dan bersih. Vidio Tutorial pembuatan Pot yang berdurasi 10.34 menit. Yang diuploud di youtube dengan link https://youtu.be/OWtYnR3RIWE

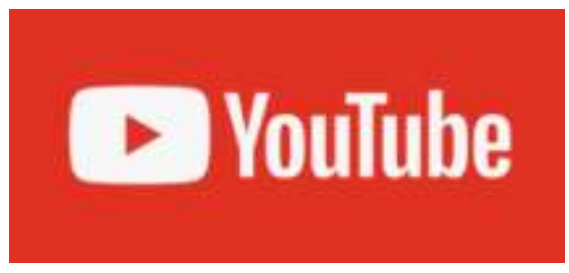

Target video untuk umum, pengambilan gambar dilakukan 3 hari tahap pencetakan, pembongkaran pasir, dan pewarnaan (finalisasi).

Dalam video terlihat masing-masing peserta dan tim PKM menggunakan masker karena pada saat itu lokasi ini menjadi zona merah, peserta dibatasi 5 anak selain menjaga prokes juga supaya lebih fokus dan inten dalam pelaksanaan.

Selain ada ilustrasi musik juga ada narasi yang langsung direkam. Pilihan back song lebih semangat ritmenya cepat.
Dalam pengambilan gambar menggunakan kamera Sony alfa dengan kualitas gambar yang baik, dengan pertimbangan angle dan arah cahaya.

Editing dibuat lebih variatif cut to cut atau dissolve. Dalam video kali ini dibuat agak singkat supaya tidak membosankan. Untuk video berikutnya akan lebih panjang dan lengkap dengan voice over dengan pengambilan gambar lebih banyak dan variatif.

Vidio semi dokumenter sebagian besar pengambilan gambar saat melakukan praktek PKM, yang dapat dijadikan materi penyusunan buku Tutorial Pembuatan Pot.

Tentu dalam kesempatan pembuatan video ini masih banyak kekurangannya namun di kesempatan lain akan lebih baik lagi. Perlu adanya evaluasi hasil video yang diunggah di Youtube, sementara ini viewer masih dibawah 100 viewer, sosialisasi akan dilakukan menggunakan beberapa media sosial. Semakin banyak yang melihat semakin banyak pula yang mengetahui kegiatan PKM ini.

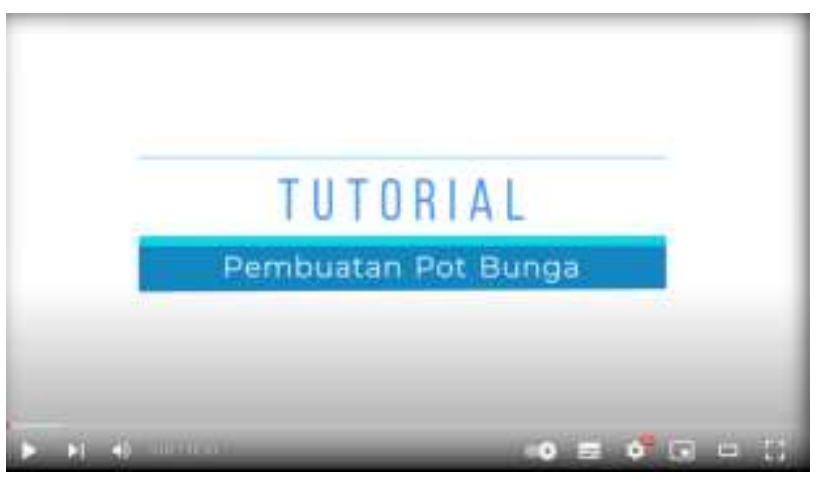

Gambar 8. Bumper

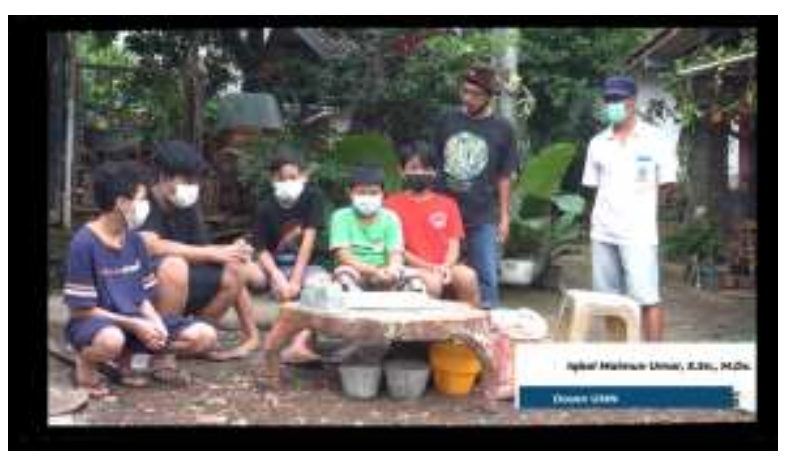

Gambar 9. Frame Pembukaan PKM 


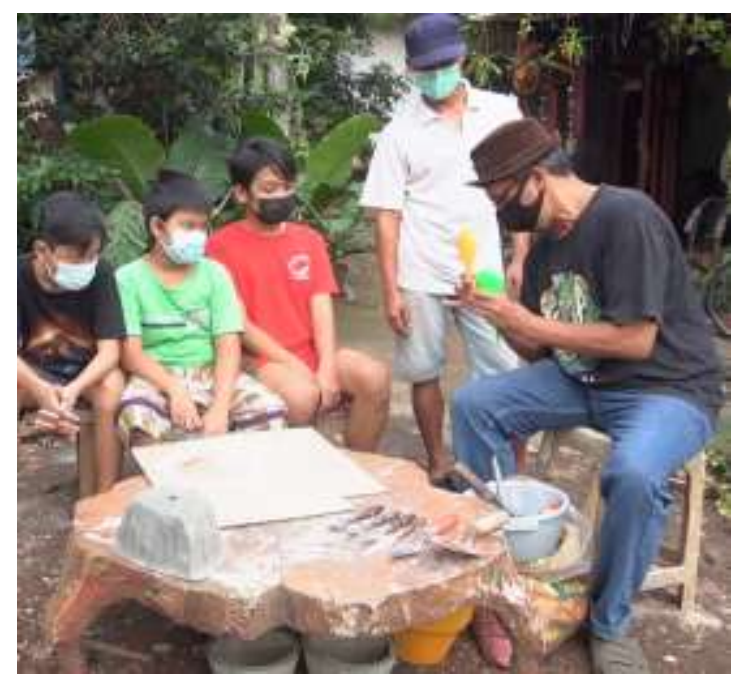

Gambar 10. Pengenalan peralatan

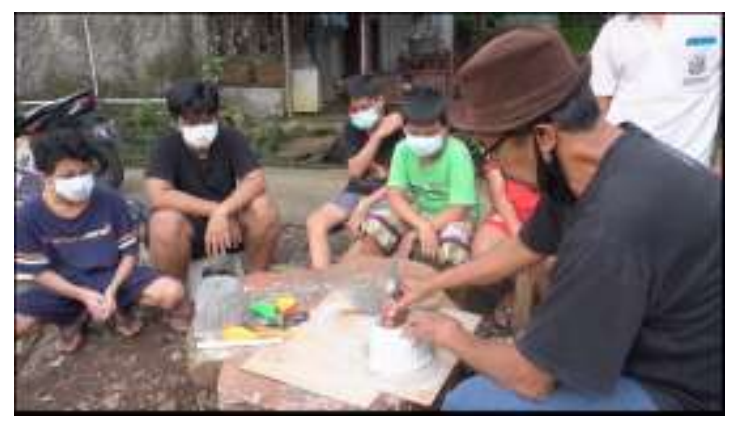

Gambar 11. cetak pasir

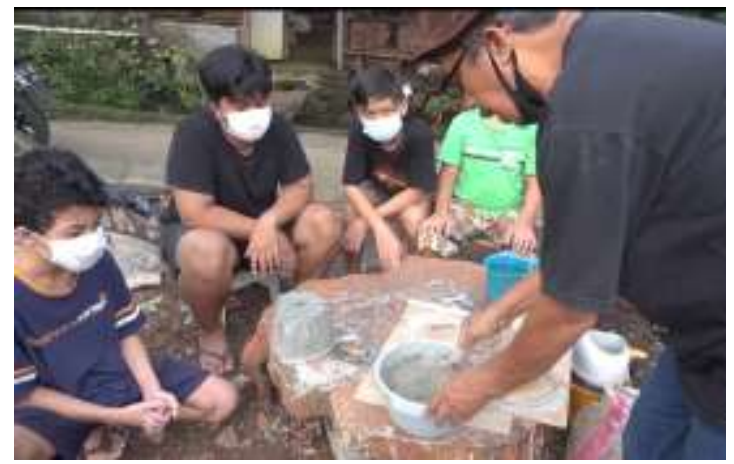

Gambar 12. Menyiapkan semen

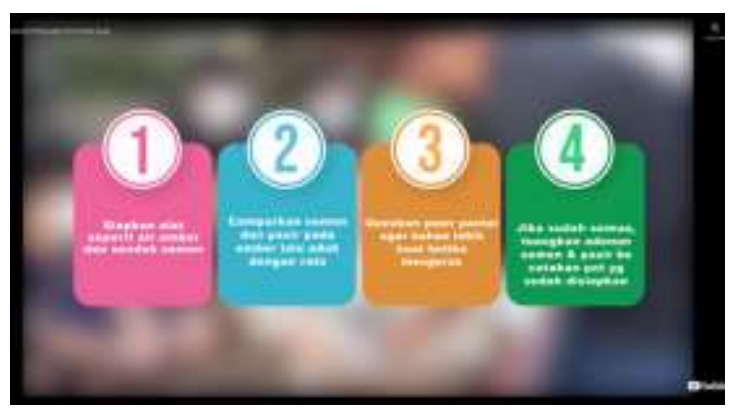

Gambar 13. Infografis tahapan

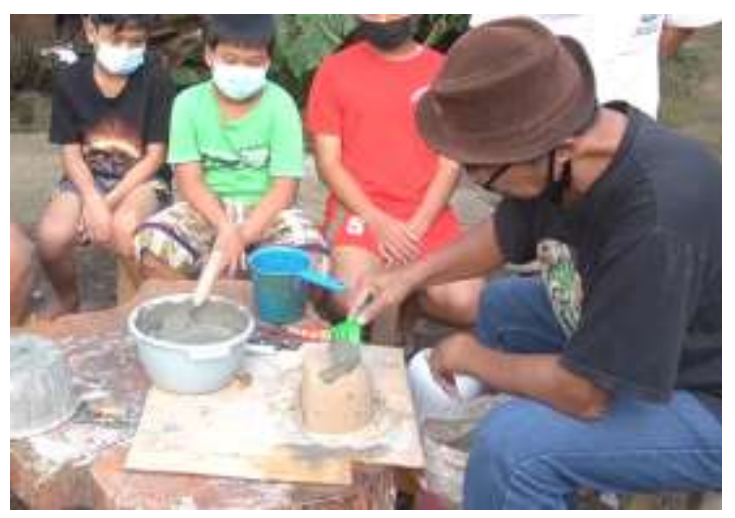

Gambar 14. Tahap plester

\section{KESIMPULAN}

Antusias peserta dan pendukung porgram PKM cukup tinggi, walau ditengah pandemi yang sedang meningkat tidak menyurutkan semangat berkarya. Dalam kondisi yang terbatas saat pandemi kita tetap dapat membuat karya, memberi pengaruh positif bagi anak-anak yang dapat membuka wawasan kreatifitas untuk masa depan mereka. Workshop ini merupakan pengalaman baru bagi anak-anak, dari awal hingga akhir proses tahap demi tahap diikuti yang dapat memunculkan rasa ingin tahu. Pembuatan POT untuk Anak-anak dari bahan semen masih jarang dilakukan. Untuk PKM mendatang perlu dilakukan pelatihan ketrampilan membuat wastafel di pasca pandemi. 


\section{SARAN}

Kegiatan ini dapat dilanjutkan dengan target yang berbeda misalnya anak remaja (usia produktif). Dan diproduksi secara masal diarahkan ke penjualan (UKM) sehingga dapat mengentaskan pengangguran dan mengangkat tingkat ekonomi di lingkungan kampung. Tidak hanya di bidang DKV saja PKM dapat dilaksanakan fakultas lain di kampung ini, misalnya pelatihan percakapan dalam bahasa asing. Atau ketrampilan pembuatan animasi, game yang sedang digemari oleh anak-anak.

Perlu penambahan instruktur, tidak hanya saat PKM bisa juga dalam program khusus yang tujuannya sama untuk meningkatkan ketrampilan.

\section{UCAPAN TERIMAKASIH}

Terimakasih kepada semua pihak yang telah memberi kesempatan dalam submited Prosiding PKM CSR 2021. Terimakasih juga saya ucapkan untuk Ketua LPPM Universitas Multimedia Nusantara Bapak P.M. Winarno dan Bapak Indiwan Seto W. sebagai ketua PKM serta timnya pak Andy dan $\mathrm{Bu}$ Wuri, dan rekan-rekan dosen di UMN pak Joni Nur Budi sebagai partner di PKM ini Bpk Muhammad Rizaldi sebagai Prodi DKV yang telah memberi suport. Dan rekan-rekan dosen tak dapat disebutkan satu persatu, slam dan apresiasi tertinggi atas suportnya.

\section{REFERENSI}

https://eprints.uny.ac.id/7942/3/bab2\%20-\%2009111247010.pdf

Dzulfaroh Ahmad Naufal https://www.kompas.com/tren/read/2020/06/22/191500765/hobi-bersepeda-selamapandemi-corona-kesadaran-atau-hanya-latah-?page=all.

Kartono, Kartini https://bbsagriculture.com/2021/03/01/memilih-jenis-pot-bagian-3-bercocok-tanam-tanaman-hiasdalam-pot/

https://www.youtube.com/watch?v=A3eTZAef $1 \mathrm{Wc}$ 